\title{
UPAYA PENCEGAHAN VIRUS COVID-19 MELALUI PEMANFAATAN TEKNOLOGI DI KELURAHAN PAJANG KOTA TANGERANG
}

\author{
Woelandari Fathonah \\ Universitas Sultan Ageng Tirtayasa, Jl. Raya Palka Km 3, Serang Banten, Indonesia \\ email: woelandari@untirta.ac.id
}

\begin{abstract}
Based on the records of the COVID-19 handling task force on July 1, 2021, the city of Tangerang is included in the COVID-19 red zone. Pajang Village is one of the villages in the Tangerang city area. This community service activity is carried out as an effort to prevent the spread of the COVID-19 virus in Pajang Village through the use of technology. This community service activity aims to minimize the spread of the COVID-19 virus through the distribution of posters and videos to local residents. This activity was carried out in stages consisting of preparation, making posters and videos about COVID-19, distributing posters and videos virtually and evaluating activities. For making posters, the process of collecting information related to the posters to be made is carried out. On the poster, points related to the poster's theme are presented. Similar to posters, making a video is done by studying literature first and then applying it in the form of a video. The videos made can convey brief information in informative language. The distribution of posters and videos is done through social media such as whatsapp, youtube and instagram. Through this activity, posters and videos have been successfully distributed through social media such as Instagram which is integrated with the Benda sub-district Instagram, YouTube and Whatsapp. Efforts to handle the spread of COVID-19 through the use of technology are quite effective during PPKM. The results of this activity received a fairly good response from the kelurahan and the local community and it is hoped that in the face of this COVID-19 pandemic, the local community will continue to carry out health protocols wherever they are and it is necessary to carry out further incentive activities in an effort to prevent the spread of COVID-19.
\end{abstract}

Keywords: COVID-19; Prevention; Spread; Technology.

\begin{abstract}
ABSTRAK
Berdasarkan catatan satgas penanganan COVID-19 tanggal 1 juli 2021, kota Tangerang masuk dalam zona merah COVID-19. Kelurahan Pajang merupakan salah satu kelurahan yang berada di wilayah kota tangerang. Kegiatan pengabdian masyarakat ini dilakukan sebagai upaya dalam mencegah penyebaran virus COVID-19 di Kelurahan Pajang melalui pemanfaatan teknologi. Kegiatan pengabdian masyarakat ini bertujuan untuk meminimalisir penyeberan virus COVID-19 melalui penyebaran poster dan video kepada warga setempat. Kegiatan ini dilakukan dengan tahapan terdiri dari persiapan, pembuatan poster dan video seputar COVID-19, penyebaran poster dan video secara virtual dan evaluasi kegiatan. Untuk pembuatan poster dilakukan dengan proses pengumpulan informasi terkait poster yang akan dibuat. Pada poster disampaikan poin-poin yang berkaitan dengan tema poster. Sama halnya dengan poster, pembuatan video dilakukan studi literatur terlebih dahulu lalu diaplikasikan dalam bentuk video. Video yang dibuat dapat penyampaian informasi singkat dengan bahasa yang informatif.. Penyebaran poster dan video dilakukan melalui sosial media seperti whatsapp, youtube dan instagram. Melalui kegiatan ini telah berhasil dilakukan penyebaran poster dan video melalui media sosial seperti instagram yang terintegrasi dengan instagram kecamatan Benda, YouTube dan Whatsapp. Upaya penanganan penyebaran COVID-19 melalui pemanfaatan teknologi cukup efektif dilakukan dimasa PPKM. Hasil kegiatan ini mendapatkan respon yang cukup baik dari pihak kelurahan dan masyarakat setempat dan diharapkan dalam menghadapi pandemic COVID-19 ini, masyarakat setempat tetap menjalankan protokol kesehatan dimanapun berada dan perlu dilakukannya kegiatan insentif lanjutan dalam upaya pencegahan penyebaran COVID-19.
\end{abstract}

Kata Kunci: COVID-19; Pencegahan, Penyebaran; Teknologi. 


\section{PENDAHULUAN}

Coronavirus merupakan virus yang dapat menyebabkan gejala ringan, berat hingga meninggal dunia (WHO., 2020). Terdapat dua jenis coronavirus yang diketahui menyebabkan penyakit pada manusia, yaitu Middle East Respiratory Syndrome (MERS-CoV) dan Severe Acute Respiratory Syndrome (SARS-CoV) (Kemenkes RI., 2020). Virus COVID-19 ini dapat menyerang manusia bagian pernapasan akut seperti demam, batuk, dan sesak napas.Pada kasus yang berat, penyakit ini dapat menyebabkan pneumonia, sindrom pernapasan akut, gagal ginjal, dan bahkan kematian. Gejala penyakit ini dapat muncul dalam 2-14 hari setelah terpapar virus tersebut (Kemenkes RI, 2020). Gejala berat akan di alami oleh usia lanjut dan memiliki penyakit penyerta.

Virus ini menular dengan sangat cepat dan telah menyebar ke hampir semua negara (Candra et al., 2020). Besarnya angka kejadian COVID-19 disertai oleh luasnya informasi mengenai penyakit ini, tetapi masih banyak terdapat disinformasi dan misinformasi di masyarakat yang berujung dengan kepanikan berlebihan (Syakurah, \& Moudy., 2020).

Kota Tangerang menjadi salah satu kota di Provinsi Banten yang ditemui terdapat cukup banyak pasien yang terkonfirmasi virus COVID-19. Kelurahan pajang merupakan bagian dari kota Tangerang, dimana ikut dalam peningkatan kasus COVID-19 dan termasuk dalam zona merah. Berdasarkan data terkini tanggal 12 Agustus 2021 yang diunggah Pemerintah Kota Tangerang melalui situs tangerangkota.go.id/corona, di kelurahan Pajang tercatat 6 suspek aktif dirawat, 56 konfirmasi sembuh, 5 konfigurasi dirawat dengan keterangan tidak adanya korban jiwa yang meninggal dunia. Kasus COVID-19 yang terjadi di Kelurahan pajang dapat dikatakan dalam kasus yang rendah, jika dibandingkan dengan kelurahan yang masih dalam satu kawasan atau wilayah Kecamatan Benda.

Kelurahan Pajang merupakan salah satu kelurahan di wilayah Kecamatan Benda, Kota Tangerang yang jumlah penduduknya yaitu 8.597 jiwa dan memiliki luas wilayah $0,62 \mathrm{~km}^{2}$. Batas wilayah Kelurahan Pajang meliputi :

Sebelah utara berbatasan dengan Bandara Soekarno - Hatta.

Sebelah timur berbatasan dengan Kelurahan Jurumudi.

Sebelah selatan berbatasan dengan Kelurahan Belendung.

Sebelah barat berbatasan dengan Kelurahan Belendung. 


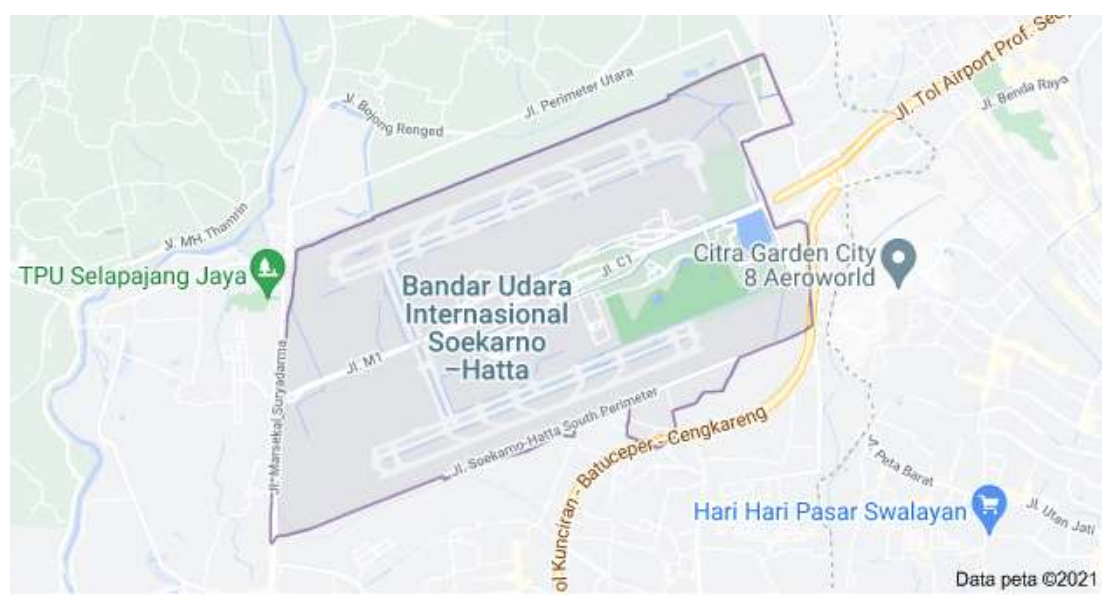

\section{Gambar 1. Lokasi Kelurahan Pajang Kecamatan Benda Kota Tangerang}

(Sumber: Google Maps diakses tanggal 12 Agustus 2021)

Penyebaran COVID-19 tidak dapat dikendalikan dan dapat meyebar secara cepat di Kampung, sehingga perlu diberikan edukasi dan sosialisasi kepada masyarakat terkait informasiinformasi yang berkaitan dengan virus COVID-19 ini (Kurniawati et al., 2019). Sosialisasi yang dapat dilakukan di masa PPKM diberlakukan adalah melalui pemanfaatan teknologi,sebagaimaa yang tercantum dalam SE MENKES HK.02.01/MENKES/303/2020 menetapkan bahwa tujuan penyelenggaraan pelayanan kesehatan melalui pemanfaatan teknologi informasi dan komunikasi sebagai salah satu langkah untuk mencegah penyebaran COVID-19. Upaya penanggulangan virus COVID-19 pada kegiatan ini yaitu membuat poster dan video yang berisikan informasi terkait virus COVID-19 dan variannya, tata cara mencuci tangan yang benar, cara menggunakan masker yang benar, cara membuat handsanitizer alami dan desinfektan dengan bahan-bahan yang mudah didapatkkan, informasi tentang pentingnya vaksin untuk mengurangi terinfeksi virus dan meringankan gejala bila terinfeksi, serta tata cara isolasi mandiri.

Penelitian ini bertujuan untuk meningkatkan wawasan dan pengetahuan masyarakat terkait virus COVID-19, sehingga masyarakat mampu menerapkan protokol kesehatan dengan benar dan meminimalisir penyebaran virus COVID-19 di Desa Pajang Kota Tangerang.

\section{METODE}

Tahapan terdiri dari persiapan, pembuatan poster dan video seputar COVID-19, penyebaran poster dan video secara virtual dan evaluasi kegiatan. Persiapan kegiatan yang akan dijalankan di lakukan 1 minggu sebelum hari pelaksanaan, pada tahap ini dilakukan sosialisasi terkait program kerja yang akan dilaksanakan kepada pihak kelurahan. Untuk pembuatan poster dilakukan dengan proses pengumpulan informasi terkait poster yang akan dibuat. Pada poster 
dilampirkan poin-poin yang berkaitan dengan tema poster. Sama halnya dengan poster, pembuatan video dilakukan studi literatur terlebih dahulu lalu diaplikasikan dalam bentuk video. Video yang dibuat dapat penyampaian informasi singkat ataupun tata cara pembuatan suatu produk yang dapat dimanfaatkan sebagai handsanitizer. Penyebaran poster dan video dilakukan melalui social media seperti whatsapp, youtube dan instagram yang terintegrasi dengan instagram Kecamatan Benda. Penyebaran melalui whatsapp dilakukan melalui whatsapp sekertaris lurah pajang yang kemudian disebarkan ke RT dan RW setempat. Tahap evaluasi dilakukan setiap minggu setelah program kerja dilaksanakan sebagai evaluasi untuk kegiatan selanjutnya.

\section{PEMBAHASAN}

Pelaksanaan kegiatan yang dilakukan secara virtual sebagai upaya dalam pencegahan COVID-19 di Kelurahan Pajang melalui pemanfatan teknologi. Kegiatan ini direspon positif dan baik oleh pihak kelurahan. Pada proses penyebaran poster maupun video dilakukan penyebaran melalui media sosial Instagram dan YouTube. Untuk penyebaran secara implisit dilakukan komunikasi maupun kerja sama dengan pihak Kelurahan Pajang yaitu sekertaris kelurahan Pajang. Pada penyeberan ini, komunikasi dilakukan secara langsung dengan sekertaris Kelurahan Pajang dalam bentuk pengiriman hasil poster dan video melalui WhatsApp. Hasil pengiriman yang dilakukan dengan sekertaris Kelurahan Pajang diteruskan kepada warga melalui WhatsApp Grup RT/RW setempat. Penyebaran poster dan video seputar COVID-19 ini sebagai upaya dalam mencegah penyebaran COVID-19.

Tabel 1. Tahapan Pelaksanaan Kegiatan

\begin{tabular}{|c|c|c|c|}
\hline $\begin{array}{c}\text { Waktu } \\
\text { Pelaksanaan } \\
\end{array}$ & Nama Kegiatan & $\begin{array}{c}\text { Poster/Video } \\
\text { (melalui Instagram dan Whatsapp) }\end{array}$ & Hasil \\
\hline $\begin{array}{l}\text { Jumat, } 30 \\
\text { juli } 2021\end{array}$ & $\begin{array}{l}\text { Membuat poster } \\
\text { mengenai apa itu } \\
\text { virus Corona (cov- } \\
\text { 02) dan varian } \\
\text { terbaru }\end{array}$ & $\begin{array}{l}\text { CORONA } \\
\text { CIRUS } \\
\text { SARSCOVV-2 } \\
\\
\end{array}$ & $\begin{array}{c}\text { Saat menyampaikan } \\
\text { rancangan pogram, } \\
\text { pihak kelurahan } \\
\text { sangat antusias } \\
\text { pada kegiatan ini, } \\
\text { meskipun masa } \\
\text { PPKM tapi } \\
\text { informasi terkait } \\
\text { virus COVID-19 ini } \\
\text { tetap tersampaikan } \\
\text { ke masyarakat. } \\
\text { Masyarakat } \\
\text { memahami virus } \\
\text { COVID-19 dan } \\
\text { varian terbarunya. }\end{array}$ \\
\hline
\end{tabular}




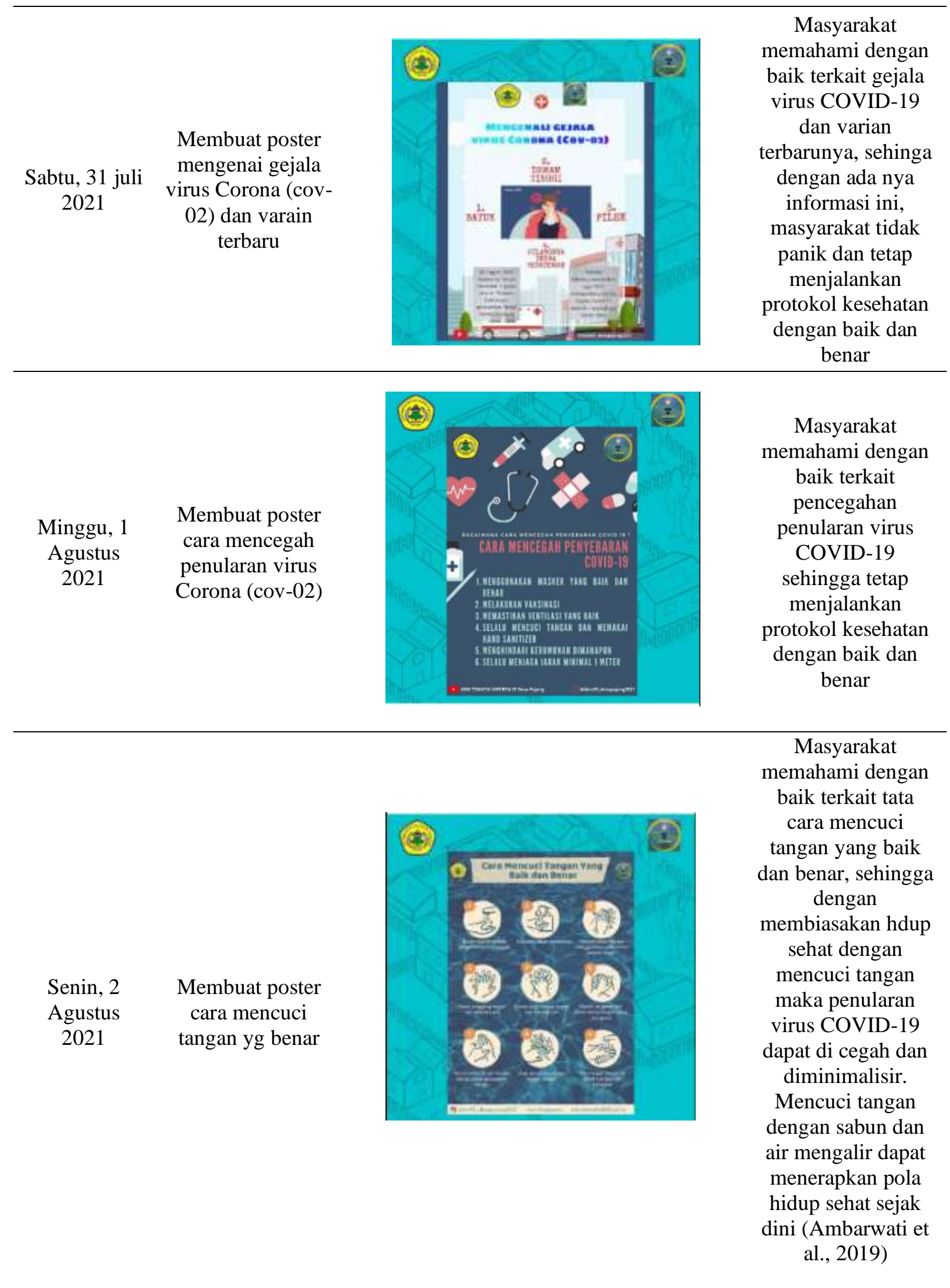


Selasa, 3

Agustus

2021

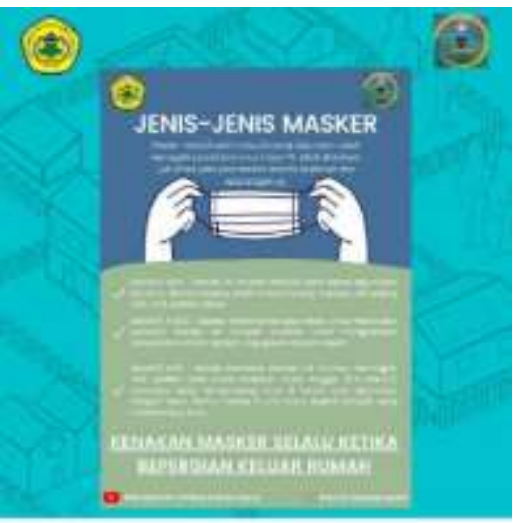

Masyarakat mendapatkan pengetahuan terkait jenis-jenis masker, dan masker yang seperti apa yang layak digunakan dalam mencegah penularan virus COVID-19.
Rabu, 4 Agustus 2021 Membuat video penggunakan masker yang benar
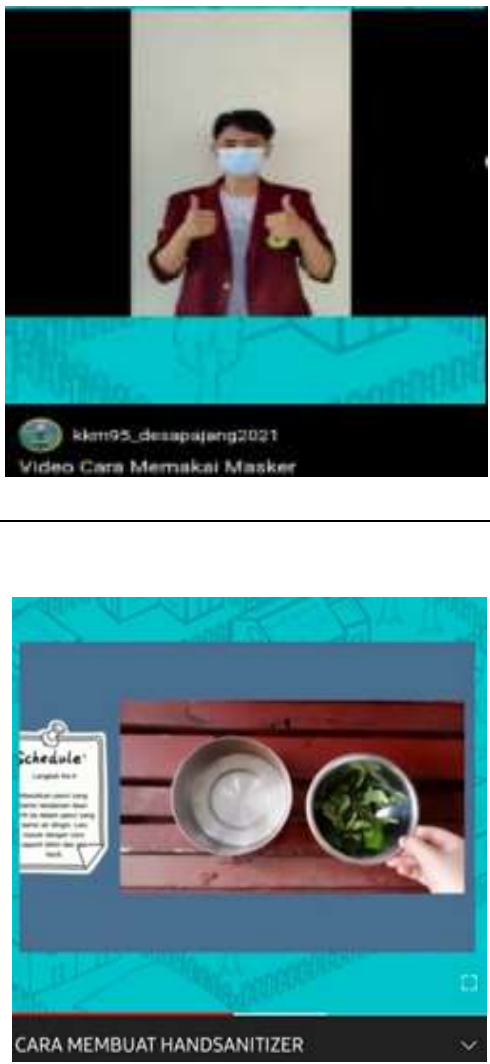

Masyarakat memahami dengan baik terkait penggunaan masker yang benar, sehingga penularan virus COVID-19 dapat dicegah dan diminimalisir
Jumat, 6

Agustus 2021

Cara membuat hand sanitizer alami (video)
Masyarakat mendapatkan pengetahuan dalam membuat hand sanitizer alami dengan menggunakan tanaman di sekitar tempat tinggal yaitu menggunakan daun sirih sehingga lebih ekonomis dengan membuat hand sanitizer sendiri

Masyarakat mendapatkan pengetahuan dalam membuat desinfektan dengan menggunakan bahan yang mudah didapatkan sehingga lebih ekonomis dengan membuat desinfektan sendiri 
Minggu, 8 Apa itu vaksin dan

Agustus

Kegunaan ap aitu

2021

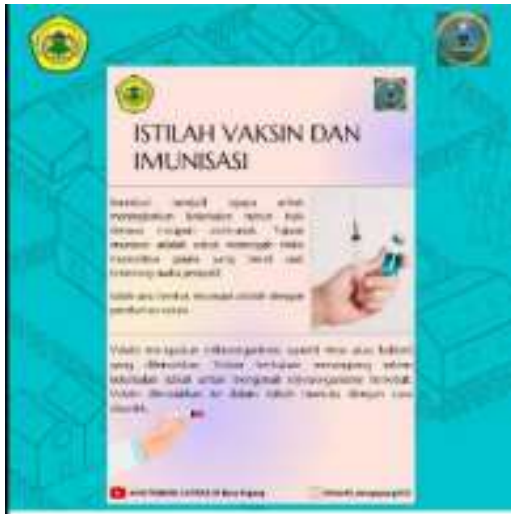

Masyarakat mendapatkan pengetahuan terkait kegunaan vaksin yang bertujuan untuk mengurangi resiko terinfeksi virus COVID-19 dan mengurangi gejala yang berat bila terinfeksi, sehingga dengan adanya informasi ini masyarakat tidak takut lagi untuk di vaksin.

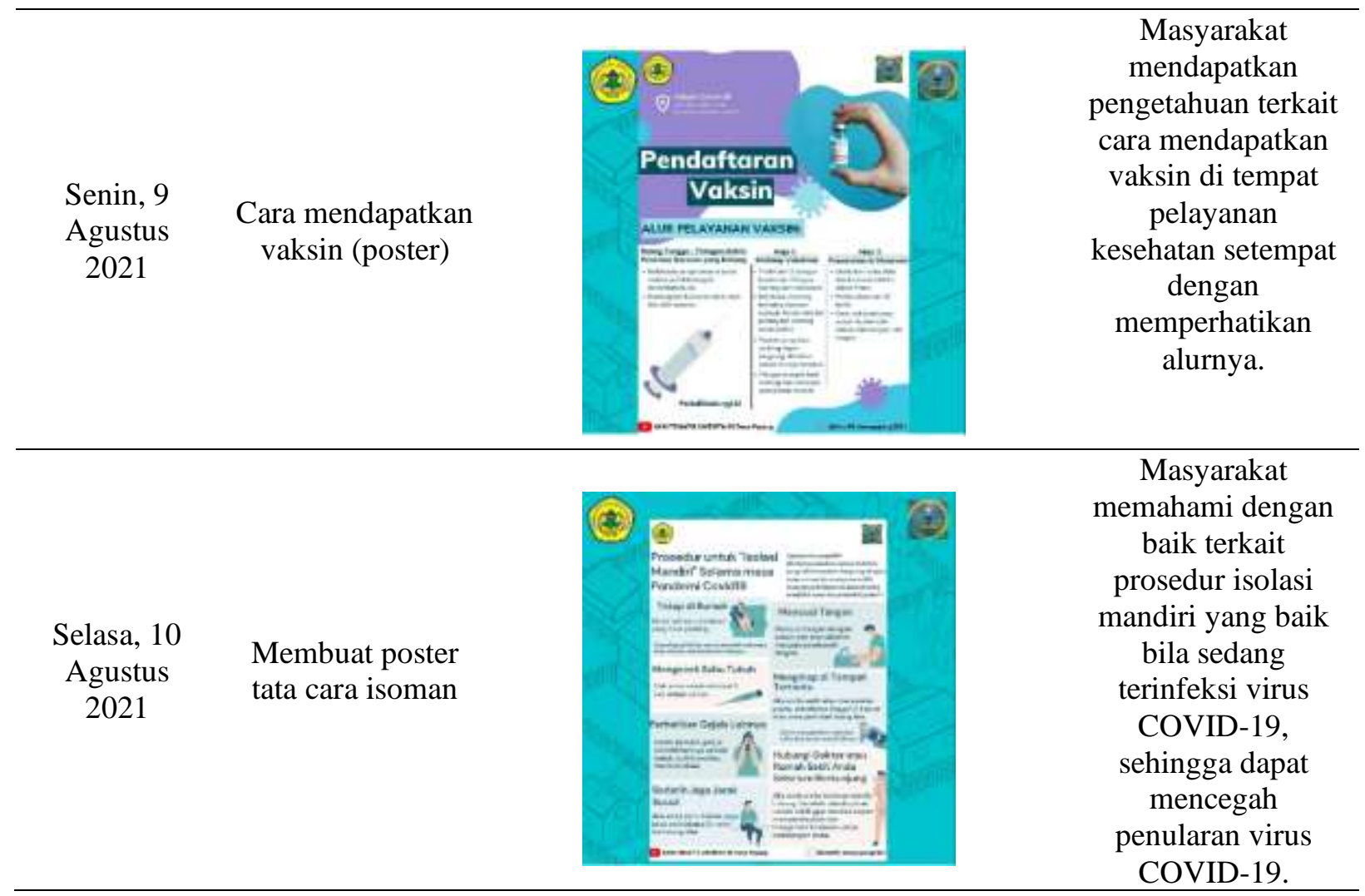

Berdasarkan kegiatan yang sudah dilakukan, kegiatan ini cukup efektif dilakukan dimasa PPKM dan masyarakat merespon dengan baik, diharapkan dari kegiatan ini melalui poster dan video yang disampaikan kepada masyarakat setempat mampu dipahami dengan baik dan memberikan wawasan/pengetahuan tambahan terkait virus COVID-19 sehinga penularan virus ini dapat dicegah. 


\section{KESIMPULAN}

Upaya penanganan COVID-19 melalui pemanfaatan teknologi memiliki tantangan tersendiri, dimana harus menghadirkan tampilan yang menarik dan informatif. Penggunaan teknologi selain memberikan tantangan, terdapat pula sebuah kemudahan dengan memperluas penyebaaran informasi mengenai COVID-19. Kegiatan dengan pemanfaatan teknologi ini dirasa mempermudah penyebarannya dan mendapatkan respon yang baik dari pihak kelurahan Pajang dan masyarakat setempat. Kegiatan ini dilakukan cukup efektif di masa PPKM. Namun, ada beberapa kendala tersendiri dari internal kelurahan pajang, dimana masih ada ketidaakpahaman terkait teknologi di masa kini. Sehingga perlu adanya kerja sama dengan pihak sekitar, yaitu aparat kelurahan pajang untuk memberikan informasi secara langsung kepada masyarakat sekitar, agar informasi yang tersampaikan diterima secara maksimal oleh masyarakat setempat.

\section{UCAPAN TERIMA KASIH}

Terima kasih kepada teman-teman mahasiswa kelompok 95 KKM Tematik Universitas Sultan Ageng Tirtayasa yang telah berpartisipasi dalam kegiatan pengabdian kepada masyarakat di Kelurahan Pajang Kecamatan Benda Kota Tangerang.

\section{DAFTAR PUSTAKA}

Ambarwati, E. R., \& Prihastuti, P. (2019). Gerakan Masyarakat Hidup Sehat (Germas) Mencuci Tangan Menggunakan Sabun Dan Air Mengalir Sebagai Upaya Untuk Menerapkan Perilaku Hidup Bersih Dan Sehat (Phbs) Sejak Dini. Celebes Abdimas: Jurnal Pengabdian Kepada Masyarakat, 1(1), 45-52.

Badan Pusat Statistik Kota Tangerang. (2020). Kecamatan Benda dalam Angka 2020. Kota Tangerang : Badan Pusat Statistik.

Candra, A. I., Santoso, S., Hendy, H., Ajiono, R., \& Nursandah, F. (2020). Upaya Pencegahan Penyebaran Virus Covid-19 Di Kelurahan Lirboyo Kota Kediri. Jurnal Ilmiah Pangabdhi, 6(2), 150-153.

Depkes RI. 2009. Panduan Penyelenggaraan Cuci Tangan Pakai Sabun Sedunia (HCTPS). Jakarta: Departemen Kesehatan RI.

Https://covid19.tangerangkota.go.id. Diakses pada tanggal 12 Agustus 2021 pukul 13.27 WIB.

Kementrian Kesehatan RI. (2020). Pedoman Pencegahan dan Pengendalian Coronavirus Disease (COVID-19). Jakarta Selatan: Kementrian Kesehatan RI.

Kurniawati, K. R. A., Santosa, F. H., \& Bahri, S. (2020). Sosialisasi Hidup Sehat di Tengah Wabah Virus Corona. JPMB: Jurnal Pemberdayaan Masyarakat Berkarakter, 3(1), 5865. 
Syakurah, R. A., \& Moudy, J. (2020). Pengetahuan terkait usaha pencegahan Coronavirus Disease (COVID-19) di Indonesia. HIGEIA (Journal of Public Health Research and Development), 4(3), 333-346.

WHO. (2020). WHO Director-General's remarks at the media briefing on 2019-nCov on 11

February 2020. http://www.who.int/dg/speeches/detail/who-director-generalsbriefingon-2019-ncov-on11-february-2020. 